\title{
Study of the Balance System between Some Enzymatic and Non-enzymatic Antioxidants in Blood Serum of Patients with Rheumatoid Arthritis in Mosul City, Iraq
}

\author{
Walaa A. Al-Jawadi ${ }^{1}$ Muna H. Jankeer ${ }^{2}$ \\ ${ }^{1}$ Lecturer, Professor, Optics Technologies Department, Al-Noor University College, Iraq, \\ ${ }^{2}$ Biology Department, Science College, Mosul University, Iraq
}

\begin{abstract}
Rheumatoid arthritis (RA) is a chronic systemic inflammatory disease with an unknown etiology, which effects on many tissues and organs. Therefore, the present study aimed to demonstrate the role of the rheumatoid arthritis in causing oxidative stress by studying the level of balance between Malondialdehyde MDA (as an indicator of oxidation) and non-enzymatic and enzymatic antioxidants in the blood serum of 95 patients of both sexes, whose ages ranged between (18-74) years, as well as 50 healthy people of both sexes and of the same ages of the injured, it was considered as a control group. The results showed a significant increase $(\mathrm{P} \leq 0.05)$ in the concentration of MDA in the serum of patients at $362 \%$ compared with the healthy control group. While the results showed a significant decrease in the concentration of nonenzymatic antioxidants represented by glutathione GSH, albumin land uric acid in serum at $48 \%, 17 \%$ and $6 \%$ respectively, compared with control. The results also showed a significant decrease in the activity of the enzymatic antioxidants represented by superoxide dismutase SOD and ceruloplasmin in the serum at $63 \%$ and $10 \%$ respectively, while the activity of glutathione peroxidase GPX showed a significant increase by $44 \%$ compared with control. The results of the current study showed an increase in the rising or falling of these studied variables more in female serum than males with RA. We conclude from this study a misalign of balance system between oxidants and non- enzymatic and enzymatic antioxidants, which indicates that RA disease caused oxidative stress in these patients, which leads to the long- term deterioration of the patient's condition.
\end{abstract}

Keywords: Rheumatoid arthritis, Antioxidants, Malondialdehyde, Glutathione Peroxidase.

\section{Introduction}

Rheumatiod arthritis (RA) is a chronic idiopathic systemic inflammatory disease, that causes cartilage damage bone ulcers and joint destruction in severe cases and often loss of function a lity. RA affects about $1 \%$ of the world's population and affects females more than males in a ratio of $1: 3$, this disease can begin at any age, but it often occurs in the age groups of (30-35) years, but this does not prevent it occures in children and elderly. RA affects Juveniles under the age of 16 and is called Jurenile Rheumatoid Arthritis (JRA) ${ }^{(1)}$. Oxidative stress is defined as an imbalance between free radicals produced by many cellular biological processes and the defensive susceptibility to antioxidants in the body, and is accompanied by an increase in lipid peroxidation, which results in subversive damage to different body tissues ${ }^{(2)}$. Ighodaro and Akinloye ${ }^{(3)}$ indicates that the imbalance between free radicals and the antioxidants in the cells leads to a rise in the free radicals cuff at the expense of the antiosidents cuff in those cells, to the degree that exceeds the resistance of the body, and consequently, it produces free radicals such as Reactive Nitrogen Species (RNS) and Reactive Oxygen Species, (ROS) leading to disruptive damage to different tissues in the body, which leads to organ damage, loss of biological functions, and occurrence of various diseases, including RA, various types of cancer, cardiovascular disease $\mathrm{e}^{(4)}$.

Exposure to free radicals from a variety of sources of living organisms leads to development of a series of defensive mechanics represented in the effectiveness of 
antioxidants that continuosly resist the harmful effects of free radicals formed in the body, as the body generates or provides defensive systems called antioxidants ${ }^{(5)}$, which are produced internally or supplied from external sources,So the need for antioxidants has become greater than the increase in the production of free radicals due to the contestant exposure to pollutants,toxic substances, medicines and diseases that increase oxidative stress ${ }^{(6)}$.

The present study aimed to know the level of oxidative stress caused by RA disease in patients of both sexes by studying the level of MDA which represents one of the final products of lipid peroxidation and some of non-enzymatic and enzymatic antioxidants in serum.

\section{Materials and Method}

Sample Collection: The current study included 95 patients with RA of both sexes (23 Males and 72 females), whose ages ranged between(18-74), who visited the Arthritis Division at Salam Teaching Hospital and outpatient clinics in the city of Mosul, after the disease was diagnosed by specialist doctors through a set of tests described by the American Society of Arthritis ${ }^{(7)}$, as well as 50 healthy people of both sexes with same ages of the patients and it was considered as a control group.

Measuring Biochemical Parameters: The biochemical parameters were measured in serum as follows:

1. Serum of lipid peroxidation (Malondialdehyde MDA) concentration (as oxidant marker) by thiobarbituric acid (TBA) modified method ${ }^{(11)}$

2. Serum of glutathione (GSH) concentration modified Ellman's reagent method ${ }^{(12)}$

3. Serum of albumin concentration by bromacresol green method ${ }^{(13)}$

4. Serum of uric acid concentration by urease enzymatic method ${ }^{(14)}$

5. Serum of Superoxide dismutase (SOD) activity was measured by modified photochemical Nitro Blue Tetrazolum(NBT) method ${ }^{(15)}$

6. Serum of glutathione peroxidase (GPx) activity was measured by colorimetric method ${ }^{(16)}$

Serum of ceruloplasmin activity was measured by spectrophotometric modified method ${ }^{(17)}$
Statistical Analysis of the results was carried out with Duncan's test

\section{Results and Discussion}

1. Malondialdehyde (MDA) Concentration (As oxidative indicator): Table(1) showed a significant increase $(\mathrm{P} \leq 0.05)$ in the concentration of MDA in the serum of patients with RA by $362 \%$ compared with the healthy Control group, and the results of table (2) showed a significant increase in the conc. of MDA in the serum of females patients at $367 \%$ more than conc. in the serum of male patients at $339 \%$ compared with healthy. The results of this study are consistent with previous studies, as they indicated high MDA conc. in serum of patients with RA $^{(15)}$.

Several authors suggested that increased reactive oxygen species(ROS) levels in RA may in a prooxidation environment, which in turn could result in increased MDA conc. As a result, lipid peroxidation may have a role in the pathogeneses of patients with $\mathrm{RA}^{(16)}$.

\section{Non-Enzymatic Antíoxidants Concentration}

2.1 Glutathione (GSH)Concentration (As an indicator of oxidative stress): Table (1) showed a Significant decrease $(\mathrm{P} \leq 0.05)$ in the concentration of GSH in the serum of patients with RA by $48 \%$ compared with the control. The results of table(2) also showed a significant decrease in the conc. of GSH in the serum of male and female patients with RA by $49 \%$ and $47 \%$ respectively compared to GSH conc. in the serum of healthy. The results of this study are in agreement with the findings of each of ${ }^{(17)}$.

The reason for the decrease in GSH conc. is due to the increased consumption of GSH as a non - enzymatic antioxidant(endogenous) in removing free radicals and preventing oxidation, as it transforms from the active reduced from GSH to the inactive oxidized from GSSG, GSH has a major role in protecting cells from free radicals damage, and in general that the result of infection with some diseases will lead to a decrease in GSHconc. due to the production of free radicals, which leads to its consumption as an antioxidant. GSH is an indicator of increased oxidative stress ${ }^{(18)}$. 
Table (1): The comparison of serum malondialdhyde (MDA), some non-enzymatic and enzymatic antioxidants between RA patients and healthy control group for both sexes

\begin{tabular}{|l|c|c|c|c|c|c|}
\hline \multirow{2}{*}{ Parameters } & \multicolumn{3}{|c|}{ Healthy control (n= 50) } & \multicolumn{4}{c|}{ Patients (n=95) } \\
\hline MDA conc. $(\mu \mathrm{mol} / \mathrm{L})$ & Mean \pm SD* & $\%$ & $\%$ & Mean \pm SD* & $\%$ & $\%$ \\
\hline GSH conc. $(\mu \mathrm{mol} / \mathrm{L})$ & $1.200 \pm 0.043 \mathrm{~b}$ & 100 & - & $5.543 \pm 0.388 \mathrm{a}$ & 462 & $362+$ \\
\hline Albmin conc. $(\mathrm{g} / \mathrm{dl})$ & $4.955 \pm 0.198 \mathrm{a}$ & 100 & - & $2.560 \pm 0.155 \mathrm{~b}$ & 52 & $48-$ \\
\hline Uric Acid conc. $(\mathrm{mg} / \mathrm{dl})$ & $4.348 \pm 0.129 \mathrm{a}$ & 100 & - & $3.595 \pm 0.109 \mathrm{~b}$ & 83 & $17-$ \\
\hline SOD activity $(\Delta \mathrm{O} . \mathrm{D})$ & $4.998 \pm 0.343 \mathrm{a}$ & 100 & - & $4.786 \pm 0.297 \mathrm{~b}$ & 96 & $4-$ \\
\hline GPx activity $(\mu \mathrm{mol} / \mathrm{L})$ & $0.0917 \pm 0.047 \mathrm{a}$ & 100 & - & $0.0343 \pm 0.003 \mathrm{~b}$ & 37 & $63-$ \\
\hline Ceruloplasmin activity $(\mu \mathrm{mol} / \mathrm{L})$ & $3.829 \pm 0.224 \mathrm{~b}$ & 100 & - & $5.512 \pm 0.390 \mathrm{a}$ & 144 & $44+$ \\
\hline
\end{tabular}

*The numbers are followed by different letters horizontally indicate a significant difference at the level of probability $(\mathrm{P} \leq 0.05)$ and correct reverse according Duncan's test.

The sign $(+)$ are means an increase.

The sign (-) are mean an decrease.

2.2 Albumin Concentration: Table (1) showed a significant decrease $(\mathrm{P} \leq 0.05)$ in the conc. of albumin in the serum of patients with RA by $17 \%$ compared with the healthy group. The results in Table (2) showed a significant decrease in the conc. of albumin in the serum of females with RA by $22 \%$ higher than that of males, as the ratio of decrease in the serum of males at $14 \%$ compared with the control. The results of the current study are consistent with the findings of previous studies ${ }^{(19)}$. The reason for the low albumin conc. is due to its effectiveness as a nonenzymatic antioxidant(endogenous), which contains sulfahydret (SH-) groups, which are associated with free radicals and nullify their effectiveness. Also, albumin is associated with unsaturated fatty acids found in low density lipoproteins (LDL), and it protects them from the oxidation process, which is why researchers called the albumin sacrifical antioxidant $^{(20)}$.

2.3 Uric acid concentration: Table(1) showed a slightly significant decrease $(P \leq 0.05)$ in the uric acid conc. in the serum of patients with RA by $4 \%$, and the results in table (2)also showed a nonsignificant decrease in the uric acid conc. in the serum of males with RA by $6 \%$ while in females by $2 \%$ compared with the control. The results of this current study correspond to the findings of ${ }^{(20,21)}$. The reason for the low conc. of uric acid is due to the fact that it represents a natural scavenger of proxynitrite radical. Uric acid is a non-enzymatic antioxidant,

Table 2: The comparison of serum malondialdhyde (MDA), some non-enzymatic and enzymatic antioxidants between both male and female RA patients and male and female healthy control group.

\begin{tabular}{|c|c|c|c|c|c|c|c|}
\hline \multirow{2}{*}{$\begin{array}{ll}\text { Parameters } & \text { Studied groups } \\
\end{array}$} & \multirow{2}{*}{ Sexes } & \multicolumn{3}{|c|}{ Healthy control $(n=50)$} & \multicolumn{3}{|c|}{ Patients $(n=95)$} \\
\hline & & Mean \pm SD* & $\%$ & $\%$ & Mean \pm SD* & $\%$ & $\%$ \\
\hline \multirow{2}{*}{ MDA conc. $(\mu \mathrm{mol} / \mathrm{L})$} & Males & $1.244 \pm 0.060 \mathrm{~b}$ & 100 & - & $5.456 \pm 0.321 \mathrm{a}$ & 439 & +339 \\
\hline & Females & $1.156 \pm 0.621 \mathrm{~b}$ & 100 & - & $5.396 \pm 0.624 \mathrm{a}$ & 467 & +367 \\
\hline \multirow{2}{*}{ GSH conc. $(\mu \mathrm{mol} / \mathrm{L})$} & Males & $5.160 \pm 0.385 a$ & 100 & - & $2.623 \pm 0.311 \mathrm{~b}$ & 51 & -49 \\
\hline & Females & $4.750 \pm 0.081 \mathrm{a}$ & 100 & - & $2.496 \pm 0.140 \mathrm{~b}$ & 53 & -47 \\
\hline \multirow{2}{*}{ Albmin conc. (g/dl) } & Males & $4.430 \pm 0.275 \mathrm{a}$ & 100 & - & $3.79 \pm 0.055 b$ & 86 & -14 \\
\hline & Females & $4.340 \pm 0.111 \mathrm{a}$ & 100 & - & $3.40 \pm 0.136 b$ & 78 & -22 \\
\hline \multirow{2}{*}{ Uric Acid conc. (mg/dl) } & Males & $5.763 \pm 0.202 \mathrm{a}$ & 100 & - & $5.410 \pm 0.202 \mathrm{a}$ & 94 & -6 \\
\hline & Females & $4.232 \pm 0.523 b$ & 100 & - & $4.163 \pm 0.118 b$ & 98 & -2 \\
\hline
\end{tabular}




\begin{tabular}{|c|c|c|c|c|c|c|c|}
\hline \multirow{2}{*}{$\begin{array}{ll}\text { Parameters } & \text { Studied groups } \\
\end{array}$} & \multirow{2}{*}{ Sexes } & \multicolumn{3}{|c|}{ Healthy control $(n=50)$} & \multicolumn{3}{|c|}{ Patients $(n=95)$} \\
\hline & & Mean \pm SD* & $\%$ & $\%$ & Mean \pm SD* & $\%$ & $\%$ \\
\hline \multirow{2}{*}{ SOD activity $(\Delta \mathrm{O} . \mathrm{D})$} & Males & $0.0734 \pm 0.149 \mathrm{a}$ & 100 & - & $0.0360 \pm 0.005 b$ & 49 & -51 \\
\hline & Females & $0.0719 \pm 0.111 \mathrm{a}$ & 100 & - & $0.0327 \pm 0.002 b$ & 46 & -54 \\
\hline \multirow{2}{*}{ GPx activity $(\mu \mathrm{mol} / \mathrm{L})$} & Males & $3.4350 \pm 0.138 \mathrm{c}$ & 100 & - & $4.875 \pm 0.369 \mathrm{~b}$ & 142 & -42 \\
\hline & Females & $4.224 \pm 0.278 b$ & 100 & - & $6.150 \pm 0.468 \mathrm{a}$ & 146 & -46 \\
\hline \multirow{2}{*}{ Ceruloplasmin activity $(\mu \mathrm{mol} / \mathrm{L})$} & Males & $185.93 \pm 2.005 \mathrm{c}$ & 100 & - & $165.33 \pm 1.791 d$ & 89 & $11-$ \\
\hline & Females & $232.13 \pm 1.588 \mathrm{c}$ & 100 & - & $209.78 \pm 1.967 b$ & 90 & $10-$ \\
\hline
\end{tabular}

*The numbers are followed by different letters horizontally indicate a significant difference at the level of probability $(\mathrm{P} \leq 0.05)$ and correct reverse according Duncan's test.

The sign $(+)$ are means an increase.

The sign (-) are mean an decrease

as it plays an important role in protecting cells from ROS resulting from certain diseases, which leads to its consumption as an antioxidant, it is an indicator of increased oxidative stress ${ }^{(20)}$.

However, GSH, albumin and uric acid conc. in serum were significantly lower in patients $(\mathrm{P} \leq 0.05)$ and concluded that these results suggest that increase oxidative stress present in patients with RA may lead to compensatory changes in the conc. of another antioxidants. These changes, in turn, may provide additional protection against lipid peroxidation in $\mathrm{RA}^{(17)}$.

The pathogenesis of this disease is linked with the composition of free radicals at the places of inflammation $^{(22)}$. Several studies reported a low antioxidant. Levels are a risk factors indicated that the inflammatory process produces ROS and decreased antioxidant levels, which may worsen the symptoms of the RA ${ }^{(16)}$

3. Enzymatic antioxidants: Table(1) showed a significant decrease $(\mathrm{P} \leq 0.05)$ in the activity of superoxide dismutase (SOD)and ceruloplasmin enzymes by $63 \%$ and $10 \%$ respectively, whereas the activity of glutathione peroxidase (GPx) enzyme showed a significant increase by $44 \%$ in the serum of patients with RA bycompared with the control. The results in table (2) also showed a significant decrease in the activity of SOD in female serum by $54 \%$ while in males by $51 \%$, and the results showed a significant decrease in the activity of ceruloplasmin in males by $11 \%$ while in females by $10 \%$, while showed the activity of GPx significantly increased in females by $46 \%$ while in males by $42 \%$ compared with the control group. The results of this study are identical to the findings of previous studies $^{18}$. The decreased SOD activity in serum of patients with RA may be attributed to increase of free radical especialy that the superoxide $\left(\mathrm{O}_{2}{ }^{*}\right)$ and hydrogen peroxide $\left(\mathrm{H}_{2} \mathrm{O}_{2}\right)$ inhibit the enzyme and reduce its activity. The enzyme decreased or increased according to the disease case, in this study, may indicate a degradation of these enzymatic antioxidants by free radicals during detoxification processes and it appears that increased level of $\left(\mathrm{O}_{2}{ }^{*}\right)^{(23)}$.

\section{Conclusion}

We conclude from this study that an imbalance in the balance system of oxidants, enzymatic and nonenzymatic antioxidants, had a significant impact on the deterioration of the condition of patients with RA. The RA caused oxidative stress.

Acknowledgements: The authors are very grateful to the Mosul University/Science Collage/Biology Department for their provided facilities, which helped to improve the quality of this work.

Conflict of Interest: None of the authors has any

Conflicts of Interest to declare.

\section{Source of Funding: Self}

Ethical Clearance: The project was approved by the local ethical committee (Science College,Mosul University, Iraq). 


\section{Reference}

1. Zerbini C, Clark P, Mendez - Sanchez L,Pereira $\mathrm{R}$, Messina $\mathrm{O}$ and Lane N. Biologic therapies and bone loss in rheumatoid arthritis Ostéoporos Int.2018, 31:198 - 216.

2. Mahdi J, Jewad A and Kassin M . Oxidative stress status in patients with rheumatoid arthritis. ThiQar Med. J.2018, 16 (2): 21-28.

3. Ighodaro $\mathrm{O}$ and AkinloyeO.First line defense antioxidants superoxide dismutase (SOD), catalase (CAT) and glutathione peroxidase (GPx): Their fundamental role in the entire antioxidant defense gird. Aleand. J. Med.2018, 54: 287-293.

4. Ahn B, Ranjit R,Permkumar P, Pharaoh G, Piekarz K, Matsuzaki S, Claflin D and Remmen H. Mitochondrial oxidative stress impairs contractile function but paradoxically increase muscle mass via fiber branching J. Sarco Musc. 2019, 10: 411428.

5. Satish B and Dilipkumar P. Free radicals natural autioxidants and their reaction mechanism. J. Ro.Sci. Chem. 2015,5: 27986-28006.

6. Rahal A, Kumar A, Singh V,Yadav B, Tiwari R, Chakraborty S and Dhama K. Review Article, Oxidative stress, prooxidants and antioxidants: the interplay. BioMed. Res. Int.2014, 1-19.

7. Arnett F C, Edworthy SM,Bloch DA. The American Rheumatism Association 1987 revised criteria for the classification of rheumatoid arthritis. Arth. Rheu.1988, 31(3), 315-324.

8. Guidet B and Shah S.(1989). Am. J.Physiol., 257(26). F440. Cited by Muslih, R. K,; Al - Nimer, M. S. and Al Zamely, O.y.(2002). The level of malondialdehyde after activation with $\mathrm{H} 2 \mathrm{O} 2$ and $\mathrm{CuSO} 4$ and inhibition by deferoxamine and molsidomine in the serum of patient with a cute myocardial infraction. Nat. J. Chem., 5:139-149.

9. Sedlak J and Lindsay R H. (1968)."Analytical Biochemistry". P.192. Cited by Al Zamely,O.; AlNimer,M and Muslih, R(2001).

10. Doumens B,Watson $\mathrm{W}$ and Biggs H. Albumin standerds and the measurement of serum albumin with bromocresol green. Clin. Chem. Acta. 1971,31: 87- 96 .

11. Newman DT and Price C P." Renal and nitrogen merabolism". Cited by Tietz, N.W. (1999)." Textbook of Clinical Chemistry". 3rd ed. N.R. Burtis, E. R. Ashwood, W. B. Saunders Company, Philadelphia,USA.1999. Pp.477-530.
Medico-legal Update, January-March 2021, Vol. 21, No. 1

1201

12. Brown MS and Goldstein A. (1983).Ann. Rev. Biochem., 25, 233. Cited by Al Zamely et al., (2001).

13. Emerson E. The condesation of aminoantipyrine II a new color test for phenolic Compounds. J. Org. Chem. 1943, 8(5):417-428.

14. Menden E, Boiano J, Murthy L and Petring H. Modification of phenylenediamine oxidase, method to permit non-antomated ceruloplasmin determination in batches of rat serum or plasma micro samples Analytical. 1977,10: 197-204.

15. Waqas M, Saeed U, Saeed S, Asif S, Malik A and Tariq R. Augmented points of lipid peroxidation and appearance of prophetic variables and their affiliation to develop rheumatoid arthritis. European J. Pharma. Med. Res.2019,6(6): 181-186.

16. Hammodat Z M.(2013). 1 solation and purification laten metalloproteinase-1-from patients with rheumatoid arthritis in Ninevah governorate. $\mathrm{PhD}$. Thesis. Science College, Mosul University, Iraq.

[17. Al - Youzbaki W, fatehi $\mathrm{H}$ and Yassen A .Oxidant and antioxidant status in patients with rheumatoid arthritis treated by methotrexate. Iraqi J. Comm. Med. 2013,1: 63-67.

18. Fonseca L, Nunes - Souza V, Goulart M and Robelo L. Oxidative stress in rheumatoid arthritis: What the future might hold regarding novel biomarkers and add - on therapies. Oxidative Med. Cell. Long. 2019, 16:1-17.

19. Ernest H, Stelzer k, Andreas W, ULF - Muller L and Stehle G. Albumin - based drug delivery as novel therapeutic approach for rheumatoid arthritis. J.Immunl.2003, 170:4793-4801.

20] Kleb NT. (2014). Study the level of oxidative stress and some physiological parameters of rheumatoid arthirtispateints. Msc. Thesis, Science College, Tikrit University, Iraq(In Arabic).

21. Naji ZM, Mohammed M and Muhammad M F. Uric acid asa natural scavenger of peroxy nitric in a sample of Iraqi patients with rheumatoid arthritis. Iraq J.Pharm. Sci. 2012,21(2):51-55.

22. Alorainy M. Effective of allopurinol and vitamin $\mathrm{E}$ on rat model of rheumatoid arthritis. Int. J. Health Sci. Qassim Unive .2002,2:59-67.

23. Karatas F, Ozates L, Canatan H, Halifeoglu I, Karatepe $\mathrm{M}$ and Colak R. Antioxidant status and lipid peroxidation in patients with rheumatoid arthritis.IndianJ.Med. Res.2003,118:178-181. 